16. Nuyts, Jan (2011), Pattern versus process concepts of grammar and mind. In: Brdar et al. (Hrsg.), P. 47-66.

17. Scheller, Julia (2008), Grammatik, Kognition und Imagination. Zeitschrift für Interkulturellen Fremdsprachenunterricht 13: 2 [Online unter http://zif.spz.tu-darmstadt.de/jg-13-2/beitrag/Scheller1.htm. 27.03.2013].

18. Talmy, Leonard (2000), Toward a cognitive semantics. Band 1: Concept Structuring Systems. Cambridge: MIT Press.

19. Tomasello, Michael (2003), Constructing a Language: A Usagebased Theory of Language Acquisition. Cambridge: Harvard University Press.

20. Wildgen, Wolfgang (2008), Kognitive Grammatik: Klassische Paradigmen und neue Perspektiven. Berlin: de Gruyter.

DOI https://doi.org/10.30525/978-9934-26-039-1-101

\title{
НЕОБХІДНІСТЬ РОЗШИРЕННЯ ВИБОРУ ІНТЕГРАТИВНИХ ЕЛЕКТИВНИХ КУРСІВ У СТАРШІЙ ШКОЛІ
}

\author{
Сорочан Л. Ф. \\ викладач кафедри англійської мови з методикою викладання \\ Криворізького державного педагогічного університету \\ м. Кривий Ріг, Дніпропетровська область, Україна
}

В умовах реформування та профілізації сучасної старшої школи в Україні активно впроваджується інтегроване навчання іноземних мов, забезпечуючи якісну підготовку учнів засобами міжпредметних зв'язків. На думку Сажко Л. А., саме інтегративна основа навчання іноземних мов як процес взаємопов'язаного формування мовленнєвої, мовної, лінгвосоціокультурної та навчально-стратегічної компетентностей на основі зразків іншомовної культури із залученням навчальних матеріалів інших предметів, використанням різноманітних засобів і форм навчання розширює пізнавальні інтереси учнів, розвиває їхні здібності, стимулює до самостійної та творчої діяльності [3, с. 2]. На нашу думку, у профільній старшій школі впровадження міжпредметних зв'язків має бути не тільки у використанні матеріалів уроків інших навчальних дисциплін, a, насамперед, через різноманітні інтегративні елективні курси (курси на вибір). В роботах дослідників вказано, що поєднання інтегративного курсу, який складається зі змістових фрагментів різних предметів, а також додаткового змісту, який раніше не входив до навчального процесу [2, с. 165] та елективного курсу, метою якого є розширення 
діапазону підготовки учнів, поглиблення та доповнення профільного навчання [3, с. 7] дає можливість розширити профіль в цілому або окремі профільні предмети, опанувати основи інших предметів за допомогою іноземної мови, надати профілю прикладну спрямованість [1, с. 23].

Саме тому наразі активно продовжується процес оновлення навчально-методичного забезпечення навчання іноземних мов у старшій школі, розробляються та впроваджуються різноманітні курси на вибір. Низка елективних курсів, таких як «Лінгвокраїнознавство», «Ділова іноземна мова», «Гід-перекладач», «Іноземна мова та економіка», «Іноземна мова та література» та інші успішно і широко застосовуються на сучасному етапі. Разом з тим, результати опитування, яке було проведено нами у жовтні 2020року серед учнів старших шкіл м. Кривий Ріг показують, що елективні курси наявні лише в 50,7\% шкіл, що, вочевидь, $\epsilon$ недостатнім та потребує впровадження. Крім того, необхідність розширення вибору елективних курсів відповідає сучасним потребам школярів, серед яких лише $36,6 \%$ респондентів нашого опитування задоволені їхнім достатньо широким вибором, а 46,5\% вказують на доцільність розширення спектру курсів на вибір. Разом 3 тим, для $16,9 \%$ учнів було важко вибрати курс із запропонованих курсів на вибір, тому у разі розширення елективних курсів потреби тих, хто не може визначитися із вибором, також можуть бути частково або повністю задоволені.

За результатами опитування «Історія України» та «Іноземна мова (англійська)» $є$ дуже популярними, оскільки серед наших респондентів (52,1\% яких навчаються в 10 класах і 47,9\% є учнями 11 класів) $38 \%$ вибрали для Зовнішнього Незалежного Оцінювання (ЗНО) «Історію України» та 67,6\% - «Іноземну мову (англійську)». Варто зазначити, що великий відсоток школярів на момент опитування ще не визначилися, чи будуть вони складати ЗНО із зазначених вище дисциплін $(21,1 \%$ та $16,9 \%$, відповідно). Водночас, інтеграція саме цих навчальних предметів в старшій профільній школі $є$ дуже актуальною, оскільки для вступу до багатьох закладів вищої освіти «Історія України» та «Іноземна мова» $\mathrm{E}$ конкурсними предметами 3 ваговим коефіцієнтом 0,5 або 0,2 в залежності від обраної спеціальності. Крім того. якісні знання саме англійської мови (AM) не лише сприяють особистому розвитку, а й надають широкий вибір майбутньої спеціальності, пов'язаної з філологією та можливостей отримати освіту в країнах ЄС. Це, на нашу думку, i зумовило популярність «Історії України» та «Іноземної мови» серед учнів старшої школи, які вибрали ці дисципліни для складання ЗНО в 2018 та 2019. 
Крім вдосконалення іншомовної комунікативної компетентності та поглиблення знань з історії нашої країни, інтеграція вивчення англійської мови та історії України характеризується своєю направленістю на становлення особистості учнів старшої школи, їх духовний розвиток, усвідомлення власної національно-культурної ідентичності. Іноземна мова стає засобом висловлення про об'єктивну дійсність, закономірності якої є предметом інших дисциплін. Крім того, результати опитування вказують, що 16,9\% школярів готові були обрати інтегративний елективний курс «Історія України англійською мовою» для вивчення, а 21,1\% респондентів не були готові дати чітку відповідь, отже, потенційно також можуть бути зацікавлені у його вивченні. Отже, запровадження інтегративного елективного курсу «Історія України англійською мовою» у старшій школі $є$ актуальним на даному етапі, оскільки відповідає потребам учнів старшої школи, сприяє їхньому особистому розвитку та надає широкий вибір майбутньої спеціалізації.

\title{
Література:
}

1. Бим И. Л. Профильное обучение иностранным языкам на старшей ступени общеобразовательной школы. Проблемы и перспективы. Москва, 2007. $211 \mathrm{c}$.

2. Зеня Л. Я. Навчання іноземних мов у старшій профільній школі: лекційно- практичний курс: посіб. для студ. вищ. навч. закладів. Горлівка, 2008. 340 с.

3. Сажко Л. А. Інтегративна основа навчання іноземних мов. URL : http://www. irbis-nbuv. gov. ua/cgi-bin/irbis_nbuv (дата звернення: 19.02.2021)

DOI https://doi.org/10.30525/978-9934-26-039-1-102

\section{ВНУТРІШНЯ МОТИВАЦІЯ ЯК ЗАПОРУКА УСПІШНОГО Й ЕФЕКТИВНОГО ВИВЧЕННЯ ІНОЗЕМНИХ МОВ}

\author{
Швечкова Ю. О. \\ викладач служби мовної підготовки мовного відділу \\ Начіональної академії Національної гвардї̈ України \\ м. Харків, Украӥна
}

Сьогодні ми живемо у світі, який неможливо уявити без міжнародної співпраці та, відповідно, без знання іноземних мов як одного зі способів можливості іï реалізації. Крім того, володіння ними дозволяє нам вільно 172 